\title{
Melatonin Sensitizes H1975 Non-Small- Cell Lung Cancer Cells Harboring a T790M-Targeted Epidermal Growth Factor Receptor Mutation to the Tyrosine Kinase Inhibitor Gefitinib
}

\author{
Miyong Yun ${ }^{\mathrm{a}}$ Eun-Ok Kima,b Duckgue Lee ${ }^{\mathrm{a}} \quad$ Ji-Hyun Kim ${ }^{\mathrm{a}} \quad$ Jaekwang Kim ${ }^{\mathrm{a}}$ \\ Hyemin Lee Jihyun Lee $^{\mathrm{a}}$ Sung-Hoon Kimª
}

aCollege of Korean Medicine, Kyung Hee University, Seoul, South Korea; ${ }^{b}$ Korean Medicine Clinical Trial Center, Kyung Hee University Korean Medicine Hospital, 23 Kyungheedaero, Dongdaemun-gu, Seoul, Korea

\author{
Key Words \\ Melatonin • $\mathrm{H} 1975 \cdot \mathrm{HCC} 827 \cdot \mathrm{EGFR} \cdot \mathrm{AKT} \cdot \mathrm{Bad} \cdot \mathrm{Bcl}-2$
}

\begin{abstract}
Background/Aims: The use of tyrosine kinase inhibitors (TKIs) to target active epidermal growth factor receptor (EGFR)-harbouring mutations has been effective in patients with advanced non-small-cell lung cancer (NSCLC). However, the use of TKIs in NSCLS patients with somatic EGFR mutations, particularly T790M, causes drug resistance. Thus, in the present study, we investigated overcoming resistance against the TKI gefitinib by combination treatment with melatonin in H1975 NSCLC cells harbouring the T790M somatic mutation. Methods: $\mathrm{H} 1975$ and HCC827 cells were treated with melatonin in combination with gefitinib, and cell viability, cell cycle progression, apoptosis, and EGFR, AKT, p38, Bcl-2, Bcl-xL, caspase 3 and Bad protein levels were examined. Results: Treatment with melatonin dose-dependently decreased the viability of $\mathrm{H} 1975$ cells harbouring the T790M somatic mutation compared to HCC827 cells with an EGFR active mutation. Melatonin-mediated cell death resulted in decreased phosphorylation of EGFR and Akt, leading to attenuated expression of survival proteins, such as Bcl-2, Bcl-xL and survivin, and activated caspase 3 in H1975 cells, but not in HCC827 cells. However, we did not observe a significant change in expression of cell cycle proteins, such as cyclin D, cyclin A, p21 and CDK4 in H1975 cells. Surprisingly, co-treatment of gefitinib with melatonin effectively decreased the viability of $\mathrm{H} 1975$ cells, but not HCC827 cells. Moreover, co-treatment of $\mathrm{H} 1975$ cells caused consistent down-regulation of EGFR phosphorylation and induced apoptosis compared to treatment with gefitinib or melatonin alone. Conclusions: Our findings demonstrate that melatonin acts as a potent chemotherapeutic agent by sensitising to gefitinib TKI-resistant H1975 cells that harbour a EGFR T790M mutation.
\end{abstract}

Copyright @ 2014 S. Karger AG, Basel

M. Yun and E.-O. Kim equally contributed to this work. 


\section{Introduction}

Non-small-cell lung cancer (NSCLC) is one of the most common lethal cancers worldwide and genetic mutations in NSCLC are critical in the progression to metastatic disease $[1,2]$. Mutations in epidermal growth factor receptor (EGFR), KRAS, and anaplastic lymphoma kinase (ALK) have been identified in patients with NSCLC, and a mutation in any one of these proteins can influence the response to targeted therapy [1, 2]. Activating EGFR mutations are most commonly detected in females, as well as in Asian patients with adenocarcinomas [3], where these mutations are found in $50 \%$ of the population [4].

The use of EGFR tyrosine kinase inhibitors (TKIs), such as gefitinib and erlotinib, to treat advanced NSCLC patients has become a standard of care, and other EGFR-directed therapeutics are in development [5-7]. Two groups reported EGFR kinase domain mutations, causing deletions in exon 19 and L858R in exon 21 of EGFR, in NSCLC patients treated with gefitinib $[8,9]$; these represent the first molecular targeting marker for TKI treatment. However, the T790M EGFR mutation has been detected with low frequency in NSCLC cancer patients and is considered to confer secondary resistance to TKIs [10-12]. Monotherapy with TKI in NSCLC containing the T790M EGFR mutation was correlated with a poor response rate of $14.6 \%$ [13]. Thus, development of new drugs or combination strategies to overcome resistance to TKI is required in a patient with an acquired EGFR mutation, such as T790M.

Melatonin (N-acetyl-5-methoxytryptamine) is produced primarily by the pineal gland at night and is involved in numerous physiological processes, such as circadian rhythm regulation, seasonal changes and sleep [14]. Furthermore, accumulated evidence indicated that melatonin has an important anti-tumour role with anti-proliferative, pro-apoptotic and anti-angiogenic activities [15-19]. Melatonin mediates these effects by targeting the EGFR and mitogen-activated protein kinase (MAPK) [15, 20, 21].

Thus, in the present study, we focused on the molecular mechanism mediating melatonin-induced suppression of lung cancer cell growth, and the effect of combination treatment with gefitinib in H1975 cells harbouring the active L858R mutation and the acquired mutation, T790M.

\section{Materials and Methods}

\section{Cell culture}

H1975 and HCC827 were obtained from the American Type Culture Collection (ATCC, Manassas, VA, USA). Cells were maintained at $37^{\circ} \mathrm{C}$ in $5 \% \mathrm{CO}_{2}$ in RPMI 1640 medium containing $10 \%$ heat-inactivated fetal bovine serum (FBS) and antibiotics (Welgene, South Korea). Melatonin and gefitinib were purchased from Sigma (St. Louis, MO). Melatonin was dissolved in DMSO, stored at $-70^{\circ} \mathrm{C}$, and diluted in culture medium for described experiments.

\section{Western blotting}

Total proteins from $\mathrm{H} 1975$ and HCC827 cells were extracted with RIPA buffer (50 mM Tris- $\mathrm{HCl}, \mathrm{pH}$ 7.4, $150 \mathrm{mM} \mathrm{NaCl}, 1 \% \mathrm{NP}-40,0.25 \%$ deoxycholic acid-Na, $1 \mathrm{M}$ EDTA, $1 \mathrm{mM} \mathrm{Na} \mathrm{VO}_{4}, 1 \mathrm{mM} \mathrm{NaF}$ and protease inhibitors cocktail [Roche]). Protein samples were quantified using a Bio-Rad DC protein assay kit II (BioRad, Hercules, CA) and separated by electrophoresis on $8-15 \%$ SDS-PAGE gel and electro-transferred onto a Hybond ECL transfer membrane (Amersham Pharmacia, Piscataway, NJ). After blocking with 2-5\% nonfat skim milk, the membrane was probed with antibodies for anti-EGFR, p-EGFR (Tyr1068), AKT, p-AKT (Ser473), Bcl-2, Bcl-xL, survivin, Mcl-1, p-Bad (Ser112) and C-Caspase 3 (Cell Signaling, Beverly, MA). Anti-Cyclin D, Cyclin A, p21 and CDK4 were purchased from Santa Cruz Biotechnologies (Santa Cruz, CA). Monoclonal anti- $\beta$-actin was purchased from Sigma Aldrich (St Louis, MO). Secondary antibodies coupled to horseradish peroxidase (HRP) were from Vector Lab (Burlingame, CA, USA). Expression was visualised by using enhanced chemiluminescence (ECL) (GE Health Care Bio-Sciences, NJ, U.S.A.). 
MTT assay

Cytotoxicity of melatonin and/or gefitinib was evaluated by 3-(4, 5-dimethylthiazol-2-yl)-2, 5-diphenyl tetrazolium bromide (MTT) (Sigma Chemical Co., St. Louis, MO). Cells were seeded onto a 96-well microplate at a density of $0.7 \times 10^{4}$ cells per well and treated with various concentrations of gefitinib and/or melatonin. After $48 \mathrm{~h}$ of incubation, we added $1 \mathrm{mg} / \mathrm{ml}$ MTT for $2 \mathrm{~h}$. Optical density (OD) was measured using a microplate reader (Tecan Austria GmbH, Grödig, Austria) at $570 \mathrm{~nm}$. Cell viability (\%) = [OD (Drug) - OD (Blank)] / [OD (Control) - OD (Blank)] × 100 .

\section{Apoptosis analysis by annexin V-propidium iodide (PI) double staining}

Apoptosis in gefitinib and/or melatonin-treated cells was analysed on a FACSCalibur instrument (Becton Dickinson, San Jose, CA) to define those positive for annexin V with or without PI staining. Cells were quantitated by double staining with Annexin V-FITC and PI using the Annexin V-Apoptosis Detection kit (Biovision, Milpitas, CA), according to the manufacturer's instructions.

Flow cytometry analysis

Approximately $2 \times 10^{5} \mathrm{H} 1975$ cells were suspended in $100 \mu \mathrm{l}$ PBS and $200 \mu \mathrm{l}$ of $95 \%$ ethanol were added during vortexing. The cells were incubated at $4^{\circ} \mathrm{C}$ for $1 \mathrm{~h}$, washed with PBS, and resuspended in 200 $\mu \mathrm{l}$ of $1.12 \%$ sodium citrate buffer ( $\mathrm{pH} 8.4$ ) together with $12.5 \mu \mathrm{g}$ RNase. Incubation was continued at $37^{\circ} \mathrm{C}$ for $40 \mathrm{~min}$. The cellular DNA was then stained by applying $200 \mu \mathrm{l}$ of propidium iodide $(50 \mu \mathrm{g} / \mathrm{ml})$ for $30 \mathrm{~min}$ at room temperature. The stained cells were analysed by FACScan flow cytometer for relative DNA content based on red fluorescence.

\section{Statistical analyses}

For statistical analysis of the data, Sigma plot ver. 12 software (Systat Software Inc., San Jose, CA, U.S.A.) was used. All data were presented as means \pm standard deviation (S.D.). One-way ANOVA was used for comparison of multiple groups. Student's $t$-test was used for comparison of two groups. Statistical difference was set at $p<0.05$ between control and melatonin or control and combination or gefitinib and melatonintreated groups. All experiments were carried out in triplicate.

\section{Results}

Melatonin treatment increased sub-G1 populations in $H 1975$ cells

Deletion of exon 19 and L858R in NSCLC is known to participate the response to TKI treatment, whereas the T790M point mutation of exon 20 confers resistance [22]. To verify drug sensitivity of EGFR mutations, we evaluated resistance of H1975 cells harbouring both L858R and T790 mutations to gefitinib using a cytotoxicity assay. The IC $_{50}$ of gefitinib in $\mathrm{H} 1975$ cells was $>10 \mu \mathrm{M}$ after a $48 \mathrm{~h}$ incubation, while it was $<500 \mathrm{nM}$ after a $24 \mathrm{~h}$ incubation in HCC827 cells, which have a deletion in exon 19 (Fig. 1A). In contrast, melatonin was more sensitive in H1975 than HCC827 cells after a $48 \mathrm{~h}$ incubation (Fig. 1B). Next, we compared the effects of melatonin and gefitinib on H1975 cells by cell cycle analysis. Melatonin treatment significantly increased sub-G1 populations, while gefitinib treatment did not affect cell cycle progression of H1975 cells compared to untreated control (Fig 1C and D). This indicates that melatonin is more sensitive in H1975 cells compared with gefitinib.

\section{Melatonin decreased phosphorylation of EGFR in H1975, but not in HCC827 cells}

The inhibitory effect of melatonin on the circadian-dependent tumour growth is mediated by suppression of EGFR $[15,20]$. To confirm this, we verified phosphorylation of EGFR in melatonin treated H1975 and HCC827 cells by immunoblotting. Melatonin (1 mM) effectively decreased the phosphorylation of EGFR in H1975 cells, whereas it did not affect the EGFR phosphorylation in HCC827 cells (Fig. 2A and B). In contrast, gefitinib significantly decreased the EGFR phosphorylation level in HCC827 cells, but not in H1975 cells (Fig. 2C and D). These data suggest that melatonin can regulate the phosphorylation of EGFR, while gefitinib has no effect on EGFR phosphorylation in H1975 cells. 
Fig. 1. Effects of gefitinib and melatonin on $\mathrm{H} 1975$ and HCC827 cell lines. H1975 and HCC827 cells were treated with (A) gefitinib and (B) melatonin for 24 and $48 \mathrm{~h}$ at the indicated concentrations and then measured cytotoxicity. Cells were treated with (C) gefitinib and (D) melatonin for $48 \mathrm{~h}$ and cell cycle progression was analysed by FACS. Data represent means \pm S.D. of three independent experiments. ${ }^{* *} p<0.01$ vs. untreated control.

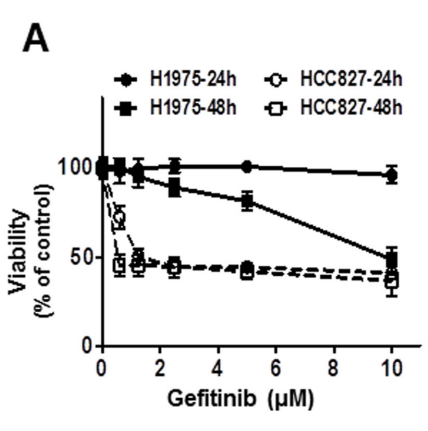

C

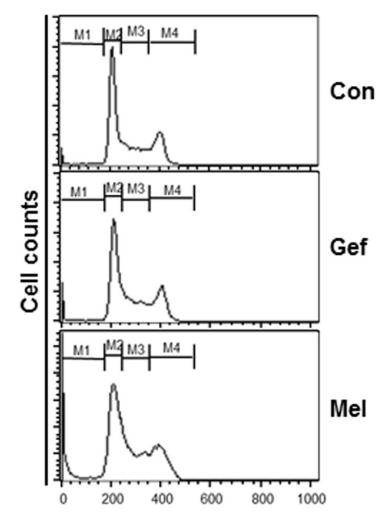

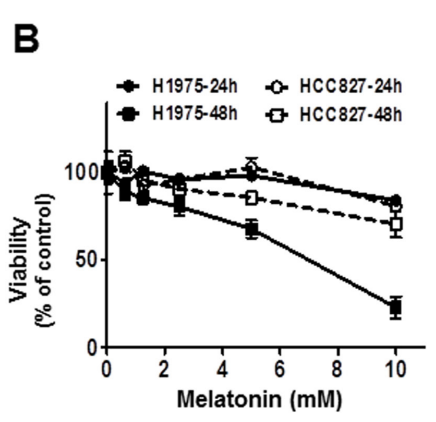

D

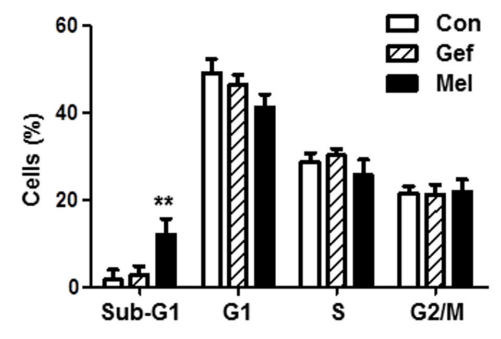

Fig. 2. Effect of melatonin on EGFR phosphorylation in gefitinibresistant H1975 cells. H1975 and HCC827 cells were treated with $(\mathrm{A}, \mathrm{B})$ gefitinib and (C, D) melatonin for $48 \mathrm{~h}$. Whole-cell extracts were prepared and analysed by Western blotting using anti-EGFR, -p-EGFR and - $\beta$-actin antibodies. Data represent means \pm S.D. of three independent experiments. ${ }^{* *} p<0.01$ vs. untreated control.
A

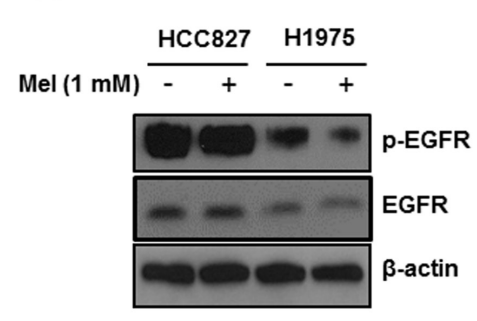

C

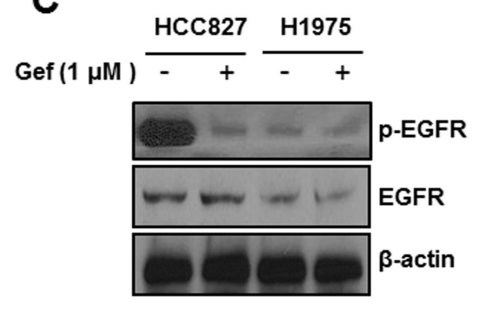

B

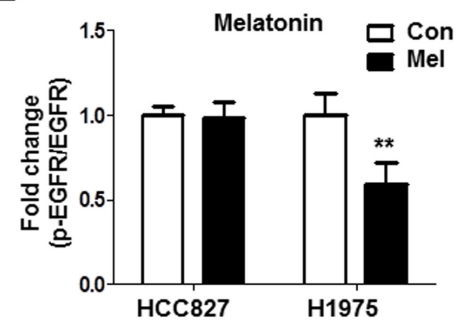

D

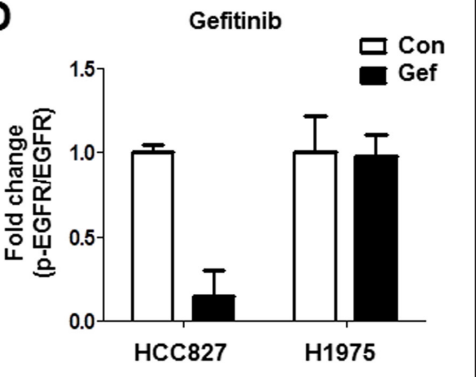

Melatonin regulates EGFR/AKT signal pathway and survival-related proteins

In Figure 2, we confirm that melatonin suppressed EGFR signalling. To verify changes in downstream target proteins induced by melatonin, Western blotting of H1975 cells was performed. We found that melatonin dramatically suppressed the phosphorylation of Akt and EGFR, but not p38 MAPK, in 1 mM melatonin-treated H1975 cells (Fig. 3A). However, melatonin did not regulate cell cycle regulators such as cyclin D, cyclin A, p21 and CKD4 
Fig. 3. Effect of melatonin on downstream EGFR targets, cell cycle progression, and apoptosis-related proteins. H1975 cells were treated with $1 \mathrm{mM}$ melatonin for $48 \mathrm{~h}$. Whole-cell extracts were prepared and analysed by Western blotting using antibodies against (A) downstream EGFR signalling targets, (B) cell cycle proteins, or (C) apoptosis-associated proteins. The same blots were stripped and re-probed with an anti- $\beta$-actin antibody to verify equal protein loading.

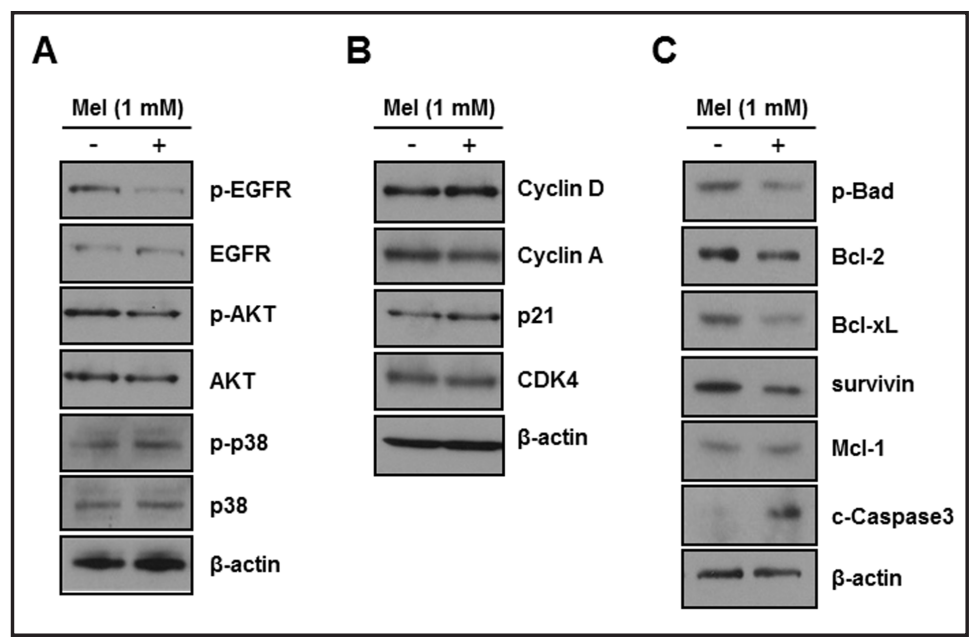

(Fig. 3B), which is consistent with Figure 1C and D. Next, we verified the levels of proteins related to cell survival. As shown Figure 3C, melatonin down-regulated p-Bad, Bcl-2, Bcl$\mathrm{xL}$ and survivin levels but did not affect that of Mcl-1. Furthermore, melatonin treatment induced cleavage of caspase3 in H1975 cells (Fig. 3C).

Melatonin increases sensitivity to gefitinib treatment in $\mathrm{H1975}$ cells

Next, we verified the combined effect of melatonin and gefitinib on HCC827 and H1975 NSCLC cells. The viability of $\mathrm{H} 1975$ cells was gradually decreased by increasing concentrations of melatonin combined with $2 \mu \mathrm{M}$ gefitinib, compared to the untreated control (Fig. 4A and B). However, co-treatment with melatonin and gefitinib showed no synergistic effect in HCC827 cells (Fig. 4A and B). Co-treatment of H1975 cells with melatonin and gefitinib suppressed EGFR phosphorylation and expression of Bcl-2 compared to application of melatonin or gefitinib alone (Fig. 4C). Furthermore, cell cycle analysis using PI and Annexin $\mathrm{V}$ staining revealed that co-treatment with melatonin and gefitinib resulted in a significant, twofold, increase in the apoptotic population in H1975 cells compared to non-treated or gefitinib-treated cells (Fig. 4D and E). These data suggest that combination treatment with melatonin and gefitinib has the potential to sensitise cells to gefitinib monotherapy in NSCLC harbouring EGFR mutations.

\section{Discussion}

NSCLC represents $85-90 \%$ of all lung cancers and includes squamous cell epidermoid carcinoma, adenocarcinoma and large-cell undifferentiated carcinoma [23]. Despite continuous efforts to develop novel molecular-targeted or combination therapies, treatment for NSCLC frequently results in drug resistance, often due to various EGFR mutations that affect TKI-targeted therapy [11]. Deletions in exon 19 and L858R in exon 21, which are dominant somatic EGFR mutations, are most common in Asian patients and confer active EGFR mutations [11, 24, 25]. Treatment response in patients with these active mutations is associated with sensitivity of NSCLC to gefitinib or erlotinib monotherapy, whereas the T790M point mutation or other mutations in exon 20 results in resistance to TKIs $[8,9,26]$. EGFR with active mutations is easily inactivated by TKIs via TKI binding to the EGFR, which restricts ATP binding in the ATP-binding pocket of EGFR. However, patients who harbour the active mutation, L858R, and the acquired mutation, T790M, developed resistance to gefitinib or erlotinib monotherapy because T790M resulted in modification of the ATP-binding pocket in EGFR, which is required for TKI access. For these reasons, development of a new drug that overcomes resistance due to inactive EGFR mutations, such as T790M, is required. This study is the first to determine that melatonin increases the sensitivity to gefitinib therapy of 


\section{Cellular Physiology and Biochemistry}

Cell Physiol Biochem 2014;34:865-872

\begin{tabular}{l|l}
\hline DOI: $10.1159 / 000366305$ & C 2014 S. Karger AG, Basel
\end{tabular} www.karger.com/cpb
Fig. 4. Effects of the gefitinib and melatonin combination on apoptosis, EGFR phosphorylation, and Bcl-2 expression. (A) HCC827 and H1975 cells were treated with the indicated concentrations of melatonin $\pm 2 \mu \mathrm{M}$ gefitinib for $48 \mathrm{~h}$, and cell viability was analysed by MTT assay. (B) HCC827 and H1975 cells were treated with $1 \mathrm{mM}$ melatonin $\pm 1 \mu \mathrm{M}$ gefitinib, and cell viability was analysed by MTT assay. (C) The expression levels of p-EGFR, EGFR, Bcl-2 and $\beta$-actin in H1975 cells treated with the indicated concentrations of melatonin and gefitinib were determined by Western blotting. $\beta$-actin served as the loading control. (D, E) Cells were treated with melatonin \pm gefitinib for 48 h. The cells were stained with propidium iodide (PI)/Annexin $\mathrm{V}$ and then analysed by FACS. Con, control; Mel, melatonin; Gef, gefitinib; $\mathrm{M}+\mathrm{G}$, melatonin and gefitinib. Values represent the standard deviation (SD); ${ }^{*} P<0.05$ vs. control. (F) Proposed scheme for apoptosis activation by melatonin in H1975 cells via inhibition of downstream EGFR signalling.
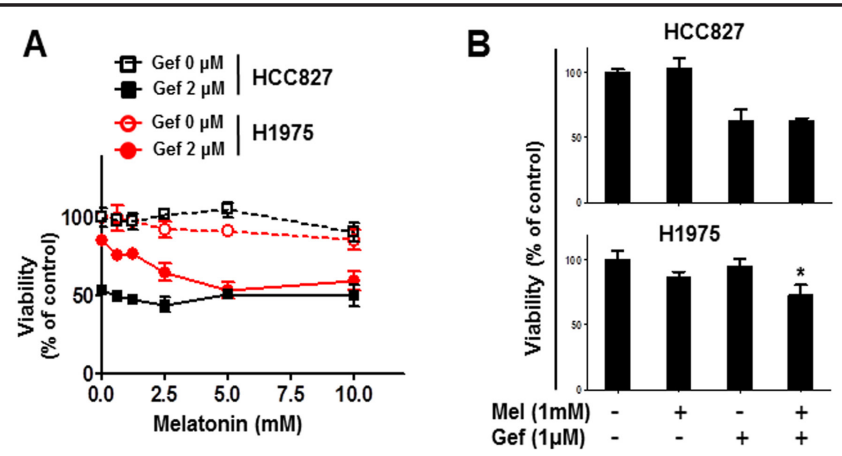

C

D

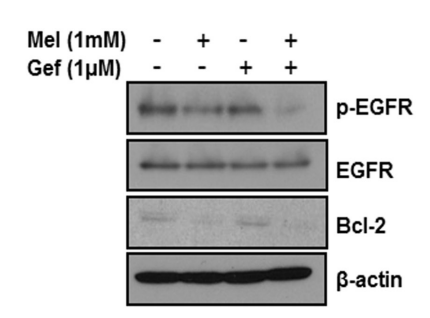

E

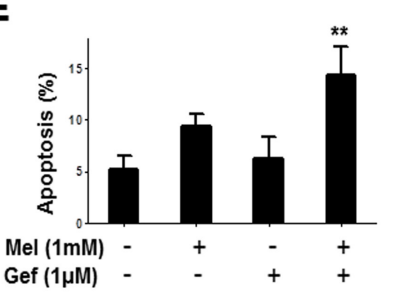

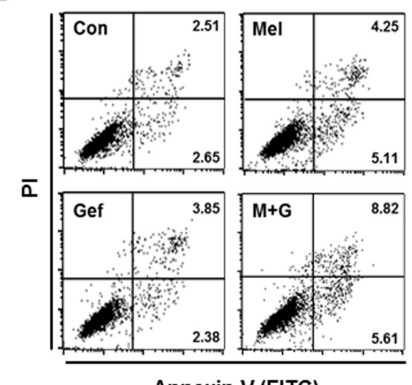

$\mathbf{F}$ Annexin V (FITC)

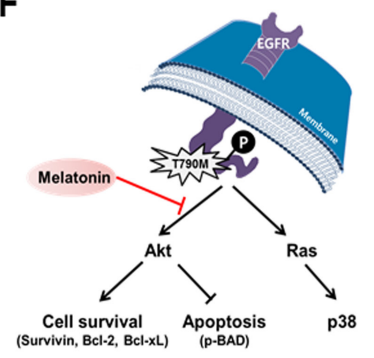

H1975 cells harbouring both L858R and T790M by inducing apoptosis. These data suggest that melatonin treatment can significantly suppress EGFR phosphorylation, which suggests the potential benefit of combination therapy with TKIs in patients with EGFR inhibitory mutations. However, further research is necessary to determine why melatonin affected EGFR phosphorylation in H1975 cells, but not HCC827 cells.

An important mechanism underlying the melatonin-mediated inhibition of tumour growth is the suppression of EGFR and activity of mitogen-activated protein kinases (MAPKs) in various cancer cell lines $[15,20,21]$. Based on our data, melatonin suppressed activation of Akt via inhibition of EGFR phosphorylation but did not affect MAPK signalling (Fig. 3). Zhou et al. reported that Akt activation, but not MAPK activation, was related to coordinated activation of receptor tyrosine kinases, EGFR, MET, and Axl in mesothelioma [27], indicating that simultaneous activation of multiple signalling pathways is required for MAPK induction. This indicates that melatonin participates only in regulation of EGFR signalling pathway, not other pathways such as MET and AXL, in H1975 cells with EGFR mutations.

Apoptosis includes an intrinsic mitochondrial pathway and extrinsic cell death pathway [28, 29]. Several proteins, such as caspases, Bcl-2 family members, and survivin, have been demonstrated to participate in the regulation of apoptosis [30-32]. Caspase cleavage is controlled by various cellular factors, including members of the Bcl-2 family. One such protein, Bad, participates in apoptotic and non-apoptotic processes controlled by phosphorylation. Growth factors such as EGF suppress the proapoptotic activity of Bad via Akt phosphorylation [33, 34]. Consistent with these reports, we found that Bcl-2 and Bad phosphorylation was dramatically decreased in melatonin-treated H1975 lung cancer cells 
(Fig. 3C). As a consequence, changes in the levels of these two proteins resulted in increased apoptosis via induction of caspase 3 activity.

Therefore, melatonin induces apoptosis and down-regulates survival related proteins such as Bcl-2 and Bad phosphorylation via inhibition of EGFR/Akt signalling. Melatonin also increases the sensitivity to gefitinib of H1975 cells containing active and somatic EGFR mutations, which leads to TKI resistance. These findings suggest that melatonin may be a potent chemotherapeutic agent in combination with gefitinib for treatment of NSCLC harbouring EGFR mutations resistant to TKI monotherapy.

\section{Disclosure Statement}

The authors disclose no potential conflicts of interest.

\section{Acknowledgment}

We thank Prof. J.K. Rho for helpful discussion and comment on the manuscript. This work was supported by the National Research Foundation of Korea (NRF) Grant funded by the Korea Government (MEST) (no. 2012-0005755).

\section{References}

1 Keedy VL, Temin S, Somerfield MR, Beasley MB, Johnson DH, McShane LM, Milton DT, Strawn JR, Wakelee HA, Giaccone G: American society of clinical oncology provisional clinical opinion: Epidermal growth factor receptor (egfr) mutation testing for patients with advanced non-small-cell lung cancer considering firstline egfr tyrosine kinase inhibitor therapy. J Clin Oncol 2011;29:2121-2127.

-2 Stella GM, Scabini R, Inghilleri S, Cemmi F, Corso S, Pozzi E, Morbini P, Valentini A, Dore R, Ferrari S, Luisetti M, Zorzetto M: Egfr and kras mutational profiling in fresh non-small cell lung cancer (nsclc) cells. J Cancer Res Clin Oncol 2013;139:1327-1335.

-3 Kerr KM: Clinical relevance of the new iaslc/ers/ats adenocarcinoma classification. J Clin Pathol 2013;66:832-838.

4 Shim HS, Lee da H, Park EJ, Kim SH: Histopathologic characteristics of lung adenocarcinomas with epidermal growth factor receptor mutations in the international association for the study of lung cancer/ american thoracic society/european respiratory society lung adenocarcinoma classification. Arch Pathol Lab Med 2011;135:1329-1334.

5 Cohen MH, Johnson JR, Chen YF, Sridhara R, Pazdur R: Fda drug approval summary: Erlotinib (tarceva) tablets. Oncologist 2005;10:461-466.

6 Sato C, Nishizawa K, Nakamura H, Komagoe Y, Shimada K, Ueda R, Suzuki S: Monoclonal antibody against microtubule associated protein-1 produces immunofluorescent spots in the nucleus and centrosome of cultured mammalian cells. Cell Struct Funct 1983;8:245-254.

7 Shepherd FA, Rodrigues Pereira J, Ciuleanu T, Tan EH, Hirsh V, Thongprasert S, Campos D, Maoleekoonpiroj S, Smylie M, Martins R, van Kooten M, Dediu M, Findlay B, Tu D, Johnston D, Bezjak A, Clark G, Santabarbara P, Seymour L: Erlotinib in previously treated non-small-cell lung cancer. N Engl J Med 2005;353:123-132.

-8 Lynch TJ, Bell DW, Sordella R, Gurubhagavatula S, Okimoto RA, Brannigan BW, Harris PL, Haserlat SM, Supko JG, Haluska FG, Louis DN, Christiani DC, Settleman J, Haber DA: Activating mutations in the epidermal growth factor receptor underlying responsiveness of non-small-cell lung cancer to gefitinib. $\mathrm{N}$ Engl J Med 2004;350:2129-2139.

-9 Paez JG, Janne PA, Lee JC, Tracy S, Greulich H, Gabriel S, Herman P, Kaye FJ, Lindeman N, Boggon TJ, Naoki K, Sasaki H, Fujii Y, Eck MJ, Sellers WR, Johnson BE, Meyerson M: Egfr mutations in lung cancer: Correlation with clinical response to gefitinib therapy. Science 2004;304:1497-1500.

10 Gow CH, Shih JY, Chang YL, Yu CJ: Acquired gefitinib-resistant mutation of egfr in a chemonaive lung adenocarcinoma harboring gefitinib-sensitive mutation 1858r. PLoS Med 2005;2:e269.

11 Kobayashi S, Boggon TJ, Dayaram T, Janne PA, Kocher O, Meyerson M, Johnson BE, Eck MJ, Tenen DG, Halmos B: Egfr mutation and resistance of non-small-cell lung cancer to gefitinib. N Engl J Med 2005;352:786-792. 
Yun et al.: Melatonin Sensitizes Gefitinib in H1975 Cells

12 Pao W, Miller VA, Politi KA, Riely GJ, Somwar R, Zakowski MF, Kris MG, Varmus H: Acquired resistance of lung adenocarcinomas to gefitinib or erlotinib is associated with a second mutation in the egfr kinase domain. PLoS Med 2005;2:e73.

13 Inukai M, Toyooka S, Ito S, Asano H, Ichihara S, Soh J, Suehisa H, Ouchida M, Aoe K, Aoe M, Kiura K, Shimizu N, Date H: Presence of epidermal growth factor receptor gene t790m mutation as a minor clone in nonsmall cell lung cancer. Cancer Res 2006;66:7854-7858.

14 Macchi MM, Bruce JN: Human pineal physiology and functional significance of melatonin. Front Neuroendocrinol 2004;25:177-195.

15 Blask DE, Sauer LA, Dauchy RT: Melatonin as a chronobiotic/anticancer agent: Cellular, biochemical, and molecular mechanisms of action and their implications for circadian-based cancer therapy. Curr Top Med Chem 2002;2:113-132.

16 Proietti S, Cucina A, Reiter RJ, Bizzarri M: Molecular mechanisms of melatonin's inhibitory actions on breast cancers. Cell Mol Life Sci 2012;70:2139-2157.

17 Rodriguez-Garcia A, Mayo JC, Hevia D, Quiros-Gonzalez I, Navarro M, Sainz RM: Phenotypic changes caused by melatonin increased sensitivity of prostate cancer cells to cytokine-induced apoptosis. J Pineal Res 2012;54:33-45.

18 Suwanjang W, Phansuwan-Pujito P, Govitrapong P, Chetsawang B: The protective effect of melatonin on methamphetamine-induced calpain-dependent death pathway in human neuroblastoma sh-sy5y cultured cells. J Pineal Res 2010;48:94-101.

19 Zhang S, Zuo L, Gui S, Zhou Q Wei W, Wang Y: Induction of cell differentiation and promotion of endocan gene expression in stomach cancer by melatonin. Mol Biol Rep 2012;39:2843-2849.

20 Haus E, Dumitriu L, Nicolau GY, Bologa S, Sackett-Lundeen L: Circadian rhythms of basic fibroblast growth factor (bfgf), epidermal growth factor (egf), insulin-like growth factor-1 (igf-1), insulin-like growth factor binding protein-3 (igfbp-3), cortisol, and melatonin in women with breast cancer. Chronobiol Int 2001;18:709-727.

21 Luchetti F, Betti M, Canonico B, Arcangeletti M, Ferri P, Galli F, Papa S: Erk mapk activation mediates the antiapoptotic signaling of melatonin in uvb-stressed u937 cells. Free Radic Biol Med 2009;46:339-351.

22 Linardou H, Dahabreh IJ, Bafaloukos D, Kosmidis P, Murray S: Somatic egfr mutations and efficacy of tyrosine kinase inhibitors in nsclc. Nat Rev Clin Oncol 2009;6:352-366.

23 Jemal A, Bray F, Center MM, Ferlay J, Ward E, Forman D: Global cancer statistics. CA Cancer J Clin 2011;61:69-90.

-24 Rosell R, Taron M, Reguart N, Isla D, Moran T: Epidermal growth factor receptor activation: How exon 19 and 21 mutations changed our understanding of the pathway. Clin Cancer Res 2006;12:7222-7231.

25 Tidow N, Boecker A, Schmidt H, Agelopoulos K, Boecker W, Buerger H, Brandt B: Distinct amplification of an untranslated regulatory sequence in the egfr gene contributes to early steps in breast cancer development. Cancer Res 2003;63:1172-1178.

-26 Huang SF, Liu HP, Li LH, Ku YC, Fu YN, Tsai HY, Chen YT, Lin YF, Chang WC, Kuo HP, Wu YC, Chen YR, Tsai SF: High frequency of epidermal growth factor receptor mutations with complex patterns in non-small cell lung cancers related to gefitinib responsiveness in taiwan. Clin Cancer Res 2004;10:8195-8203.

27 Zhou S, Liu L, Li H, Eilers G, Kuang Y, Shi S, Yan Z, Li X, Corson JM, Meng F, Zhou H, Sheng Q, Fletcher JA, Ou WB: Multipoint targeting of the pi3k/mtor pathway in mesothelioma. Br J Cancer 2014;110:2479-2488.

28 Elmore S: Apoptosis: A review of programmed cell death. Toxicol Pathol 2007;35:495-516.

29 Ouyang L, Shi Z, Zhao S, Wang FT, Zhou TT, Liu B, Bao JK: Programmed cell death pathways in cancer: A review of apoptosis, autophagy and programmed necrosis. Cell Prolif 2012;45:487-498.

-30 Czabotar PE, Lessene G, Strasser A, Adams JM: Control of apoptosis by the bcl-2 protein family: Implications for physiology and therapy. Nat Rev Mol Cell Biol 2014;15:49-63.

-31 Kroemer G, Blomgren K: Mitochondrial cell death control in familial parkinson disease. PLoS Biol 2007;5:e206.

32 Mita AC, Mita MM, Nawrocki ST, Giles FJ: Survivin: Key regulator of mitosis and apoptosis and novel target for cancer therapeutics. Clin Cancer Res 2008;14:5000-5005.

33 Datta SR, Dudek H, Tao X, Masters S, Fu H, Gotoh Y, Greenberg ME: Akt phosphorylation of bad couples survival signals to the cell-intrinsic death machinery. Cell 1997;91:231-241.

-34 Dudek H, Datta SR, Franke TF, Birnbaum MJ, Yao R, Cooper GM, Segal RA, Kaplan DR, Greenberg ME: Regulation of neuronal survival by the serine-threonine protein kinase akt. Science 1997;275:661-665. 